\title{
PENINGKATAN EFISIENSI PRODUKSI MINUMAN HERBAL INSTAN DAN KAPASITAS PRODUKSI MINUMAN HERBAL CAIR
}

\author{
Increasing Production Efficiency of Instant Herbal Drink and Production Capacity \\ of Herbal Beverage
}

\author{
Ella Saparianti ${ }^{1)}$ dan La Chovia Hawa ${ }^{2)}$ \\ 1)Jurusan Teknologi Hasil Pertanian - Universitas Brawijaya, Jl. Veteran, Malang \\ ${ }^{2)}$ Jurusan Teknologi Keteknikan Pertanian - Universitas Brawijaya, Jl. Veteran, Malang
}

\begin{abstract}
There is an increasing interest to consume herbal supplements or drinks, because traditionally Indonesian has local wisdom that believes herbal consumption will give positive effects on health. High demand of herbal drinks has encouraged two small medium enterprises (SMEs) in Batu City, "Dua Putri" and "Berkah Alam", to produce instant herbal drinks. SME "Dua Putri" produces instant herbal wild ginger, white curcuma, ginger, keji beling, betel, and sometimes noni and orange Jessamine. Meanwhile SME "Berkah Alam" produces mixed drinks from sappan wood, roselle, tamarind, curcuma, white curcuma, lemon grass/citronella, wild ginger in liquid and is known as spices drinks. Both SMEs had inefficient production due to limited equipments for herbal drink production. SME 'Berkah Alam' also had limited shelf life of its products due to inappropriate line production. The result of this activity was dissemination of cup drinks production. Increasing production was achieved by using bigger boiling pan for extraction. The capacity of slicing was also increased by using slicing machine. SME "Berkah Alam" was trained for herbal cup drink production and the functions of each step were also explained. SME "Dua Putri" had improved its packaging in pouch by using hand sealer. Sugar crystal milling was also improved by using machine as well as pressing for extraction.
\end{abstract}

Keywords: crystallization, cup, extraction, herbal

\begin{abstract}
ABSTRAK
Konsumsi herbal dalam bentuk suplemen ataupun minuman menjadi alternatif yang kian hari makin diminati. Selain itu, secara tradisional masyarakat Indonesia mempunyai kearifan lokal warisan leluhur yang meyakini bahwa mengkonsumsi bahan tertentu memberikan khasiat positif bagi kesehatan. Melihat potensi dan peluang permintaan pasar yang tinggi akan minuman herbal, dua UKM di Kota Batu yaitu UKM Minuman Herbal Instan "Dua Putri" dan UKM Minuman Enpon-empon "Berkah Alam". UKM "Dua Putri" (Mitra 1) memproduksi herbal instan temulawak, kunir putih, jahe, keji beling, sirih serta kadang-kadang mengkudu dan kemuning. UKM "Berkah Alam" (Mitra 2) memproduksi minuman campuran secang, rosela, asam jawa, kunyit, kunyit putih, serai, dan temulawak dalam bentuk sirup dan minuman yang dikenal sebagai sirup dan minuman empon-empon. Kedua mitra menghadapi proses produksi yang tidak efisien akibat keterbatasan alat. Kedua mitra juga menghadapi kesulitan dalam meningkatkan kapasitas produksi akibat kapasitas alat yang dimiliki rendah. Proses pengolahan minuman empon-empon di Mitra 2 belum tepat sehingga daya awetnya rendah. Hasil kegiatan ini adalah proses pengolahan minuman herbal dalam kemasan cup telah diintroduksikan ke Mitra 1. Kapasitas produksi minuman herbal juga meningkat dengan adanya panci perebus yang berfungsi untuk ekstraksi. Proses perajangan yang selama ini manual dapat dipercepat dnegan adanya mesin perajang empon-empon. Selain itu, Mitra 1 juga telah diberi penjelasan tentang prinsip-prinsip pengolahan minuman herbal cup dan fungsi-fungsi setiap tahapan pengolahan. Mitra 2 untuk sementara dapat memperbaiki kemasan dari kemasan plastik menjadi kemasan minuman herbal instan dalam plastik pouch. Adanya handsealer dapat memperbaiki kinerja
\end{abstract}


pengemasan Mitra 2. Alih teknologi ekstraksi empon-empon dan perbaikan proses penepungan kristal minuman instan dilakukan dengan menggunakan pengepres dan penepung.

Kata kunci: empon-empon, ekstraksi, herbal, kemasan cup, kristalisasi

\section{PENDAHULUAN}

Perkembangan penyakit degeneratif saat ini yang pesat akibat perubahan gaya hidup dan peningkatan tekanan/stress lingkungan menyebabkan sebagian orang mulai mengkonsumsi makanan dan minuman yang menyehatkan. Konsumsi herbal dalam bentuk suplemen ataupun minuman menjadi alternatif yang kian hari makin diminati. Selain itu, secara tradisional masyarakat Indonesia mem-punyai kearifan lokal warisan leluhur yang meyakini bahwa mengkonsumsi bahan tertentu memberikan khasiat positif bagi kesehatan, seperti kunyit, asam jawa, kayu secang, kunir putih, jahe dan empon-empon lainnya. Bahan tersebut diolah secara tradisional menjadi minuman herbal seperti kunyit asam, minuman secang, minuman jahe, bandrek, wedang, rosela, dan sebagainya.

Melihat potensi dan peluang permintaan pasar yang tinggi akan minuman herbal, dua UKM (usaha kecil, dan menengah) yang ada di Kota Batu yaitu UKM Minuman Herbal Instan "Dua Putri" dan UKM Minuman Enpon-empon "Berkah Alam". UKM "Dua Putri" (Mitra 1) telah memproduksi herbal instan temulawak, kunir putih, jahe, keji beling, sirih serta kadang-kadang mengkudu dan kemuning. UKM "Berkah Alam" (Mitra 2) telah memproduksi minuman campuran secang, rosela, asam jawa, kunyit, kunyit putih, serai, dan temulawak dalam bentuk sirup dan minuman yang dikenal sebagai sirup dan minuman empon-empon.

Nama ilmiah bahan herbal yang digunakan untuk kedua UKM tersebut adalah sebagai berikut: temulawak (Curcuma xanthorrhiza), kunir putih (Curcuma alba Rhizoma), jahe (Zingiber officinale), keji beling (Stachytarpheta mutabilis), sirih (Piper betle L), mengkudu (Morinda citrifolia), kemuning (Murraya paniculata), secang (Caesalpinia sappan), rosela (Hibiscus sabdariffa), asam jawa (Tamarindus indica), dan serai (Cymbopogon nardus (L.) Rendle).

Menurut Duke et al. (2002), temulawak mempunyai khasiat anti peradangan, antitumor, aperitif, carminative, cholagogue, choleretic, cox-2 inhibitor, emmenagogue, litholytic, stomachic, dan tonic. Tidak dilaporkan adanya kontraindikasi untuk temulawak pada dosis yang tepat yaitu $2 \mathrm{~g}$ rimpang atau 0,5 g bubuk rimpang 2-3 kali sehari. Jahe dilaporkan banyak mempunyai khasiat seperti analgesik (penghilang sakit), antidepresan, antibakteri, antialergi, anti peradangan, antioksidan, antilipidemia, antikanker dan lainnya. Haniadka et al. (2013) melaporkan bahwa jahe bersifat hepatoprotektif yang dapat melindungi hati dari kerusakan.

Asam jawa dilaporkan mempunyai khasiat anlagesik, antibakteri, antioksidan, antipiretik, antiseptik, antispasmodik, antiviral, hepatotropik, laksatif, dan lainnya (Duke et al., 2002). Ng et al. (2012) mengulas bahwa kemuning mempunyai aktivitas antioksidan dan antibakteri karena mengandung senyawa bioaktif berupa flavonoid, indole alkaloid, dan koumarin. Gautam et al. (2012) menunjukkan bahwa dari uji toksisitas kemuning aman dikonsumsi. Secang mempunyai khasiat sebagai antikanker (Hemalatha et al., 2011) dan bersifat sebagai antibakteri (Srinivasan et al., 2012).

$$
\text { Rosela dilaporkan oleh Al-Kennany }
$$
dan Al-Khafaf (2010) mempunyai kemampuan mencegah stres oksidatif, mencegah peroksidasi lipid, meningkatkan aktivitas enzim antioksidan dalam tubuh, dan mencegah proliferasi sel vascular smooth muscle yang berperan pada aterosklerosis. Rosela juga dilaporkan 
mempunyai aktivitas antibakteri (Chao dan Yin, 2008) dan antikapang (Alshami dan Alharbi, 2014).

Duke et al. (2002) menuliskan bahwa sirih dilaporkan berkhasiat sebagai antibakteri, antioksidan, analgesik, antilactagogue, ekspektoran, antiperistaltik, hepatotonik, dan lainnya. Mengkudu atau noni dituliskan mempunyai khasiat sebagai analgesik, antiarthritis, antipiretik, antireumatik, antitumor, antispasmodik, laksatig, hipotensif, dan sebagainya. Rosela dilaporkan bersfat sebagai anibakteri, antiskorbut, antipiretik, hipotensif, laksatif, sedatif, tonik, diuretik, dan lainnya. Ying et al. (2002) melaporkan bahwa mengkudu telah digunakan lebih dari 2000 tahun oleh bangsa Polinesia karena mempunyai efek terapeutik sebagai antibakteri, antiviral, antitumor, antihelmin, analgesik, hipotensif, antiinflamasi, dan peningkat kekebalan.

Keji beling dilaporkan berkhasiat sebagai antidiabetes (Muhtadi et al., 2013). Kunyit putih dari hasil penelitian bersifat melindungi hati dari kerusakan akibat alkohol (Lisdiana, 2004) dan antikanker, mengurangi inflamasi dan kerusakan sel otak, antimikroba, antiseptik, dan antiracun (Anonim, 2013).

Melihat khasiat dari minuman herbal yang diproduksi kedua UKM tersebut yang sudah terbukti dari penelitian ilmiah, maka prospek produk kedua UKM tersebut mempunyai prospek yang cerah untuk dipasarkan. Minuman herbal instan "Dua Putri” produksi Ibu Sumiati (Mitra 1) dipasarkan di Kota Batu. Ada dua jenis kemasan yang dijual yaitu kemasan plastik dan kemasan toples plastik (Gambar 1). Mitra 1 mmproduksi minuman herbal instan secara rutin $5 \mathrm{~kg} / \mathrm{hari}$ untuk kunyit, kunir putih, dan jahe, sedangkan minuman herbal instan yang lain seperti mengkudu, keji beling, sirih merah, dan kemuning tidak rutin diproduksi tetapi seringkali berdasarkan pesanan. Yang unik dari produk Mitra 1 ini ada produk minuman herbal instan yang jarang diproduksi oleh UKM lain yaitu mengkudu, keji beling, sirih merah, dan kemuning.
Permasalahan yang dihadapi Mitra 1 dalam proses produksi minuman herbal instan adalah proses pemarutan yang harus ke pasar yang memerlukan waktu, proses pemerasan yang masih manual dengan sehingga tidak semua sari empon-empon bisa terekstrak, dan proses penggilingan. Masalah lain adalah proses pemasakan yang masih menggunakan kompor rumah tangga.

Permasalahan yang dihadapi oleh Mitra 2 dalam produksi minuman emponempon adalah proses perajangan yang masih menggunakan alat sederhana (pasrah) serta keterbatasan kapasitas ekstrasi emponempon. Mitra juga mempunyai wilayah pasar yang terbatas akibat daya tahan produk yang rendah. Masalah lain adalah terbentuknya endapan pada produk selama penyimpanan dan pemasaran.

\section{METODE PELAKSANAAN}

\section{Peningkatan kapasitas dan efisiensi produksi minuman herbal}

Peningkatan efisiensi dan kapasitas produksi minuman herbal dibutuhkan kedua mitra untuk meningkatkan jumlah produksi dan perluasan pasar. Permasalahan yang dihadapi Mitra 1 adalah kapasitas dan efisiensi ekstraksi, kristalisasi, dan pengecilan ukuran kristal yang rendah. Peningkatan kapasitas dan efisiensi produksi minuman herbal instan dapat dilakukan dengan mekanisasi proses sehingga alat proses tersedia di tempat produksi mitra. Peningkatan kapasitas dan efisiensi ekstraksi dapat dilakukan dengan alih teknologi ekstraksi menggunakan blender denngan kapasitas lebih besar.

Mitra 1 menghadapi masalahan proses pengecilan ukuran kristal yang tidak efisien karena menggunakan blender ukuran rumah tangga dengan kapasitas $250 \mathrm{~g}$ per proses (6 menit). Untuk menghancurkan kristal sebanyak $5 \mathrm{~kg}$, Mitra 1 membutuhkan waktu proses 2 jam. Alih teknologi mekanis menggunakan mesin penepung dapat mempercepat proses pengecilan ukuran dari 2 jam menjadi 10 menit. 
Permasalahan yang dihadapi Mitra 2 dalam produksi minuman empon-empon adalah perajangan yang menggunakan peralatan pasrah sederhana sehingga memakan waktu lama yaitu 1 jam untuk 2 $\mathrm{kg}$ bahan. Mekanisasi proses perajangan menggunakan alat perajang mekanis dapat meningkatkan kapasitas produksi dari 2 $\mathrm{kg} / \mathrm{jam}$ menjadi $60 \mathrm{~kg} / \mathrm{jam}$. Masalah lain yang dihadapi Mitra 2 adalah proses pemasakan untuk mendapatkan sari emponempon atau proses ekstraksi mempunyai kapasitas kecil yaitu 5-10 L sehingga proses ekstraksi ini yang menyebabkan proses produksi menjadi lama. Penggunaan panci perebus dengan kapasitas besar $(75 \mathrm{~L})$ dapat meningkatkan kapasitas produksi Mitra 2.

\section{Perbaikan kemasan dan label produk minuman herbal}

Permasalahan yang dihadapi Mitra 1 terkait pengemasan minuman herbal instan adalah proses pengemasan yang masih tradisional menggunakan api dan proses penimbangan yang menggunakan timbangan kue. Akibatnya Mitra 1 seringkali tidak dapat mengemas dengan baik dengan berat yang tepat. Hand sealer manual dibutuhkan mitra untuk mengatasi masalah tersebut. Penimbangan dengan timbangan digital akan membantu mitra untuk meningkatkan presisi dan akurasi penimbangan. Pembuatan label juga diperlukan kedua mitra untuk memperbaiki performa produknya. Mitra 2 juga menginginkan perbaikan kemasan minuman empon-empon menjadi minuman cup dengan daya awet tinggi sehingga dapat dipasarkan secara luas. Untuk pengemasan minuman cup dibutuhkan cup sealer.

\section{HASIL DAN PEMBAHASAN}

\section{Peningkatan kapasitas dan efisiensi produksi minuman herbal}

Mitra 2 memerlukan peningkatan kapasitas dan efisiensi perajangan emponempon dan ekstraksi. Mitra 1 memerlukan peningkatan efisiensi ekstraksi emponempon untuk mendapatkan sarinya dan pengecilan ukuran kristal. Peningkatan kapasitas dan efisiensi produksi minuman herbal instan dilakukan dengan mekanisasi proses. Peningkatan efisiensi perajangan empon-empon dilakukan dengan mekanisasi perajangan menggunakan mesin perajang listrik. Selama ini Mitra 2 merajang emponempon dengan cara pengirisan menggunakan pisau. Hanya saja alat perajang yang dipesan belum selesai dibuat. Alat perajang ini didesain khusus untuk merajang empon-empon.

Peningkatan efisiensi dan kapasitas produksi minuman herbal dibutuhkan kedua mitra untuk meningkatkan jumlah produksi dan perluasan pasar. Permasalahan yang dihadapi Mitra 1 adalah kapasitas dan efisiensi ekstraksi, kristalisasi, dan pengecilan ukuran kristal yang rendah. Peningkatan kapasitas dan efisiensi produksi minuman herbal instan dapat dilakukan dengan mekanisasi proses sehingga alat proses tersedia di tempat produksi mitra. Peningkatan kapasitas dan efisiensi ekstraksi dapat dilakukan dengan alih teknologi ekstraksi menggunakan pengepres manual dengan kapasitas $2 \mathrm{~kg}$ empon-empon (Gambar 1). Pengepres manual ini bertujuan menggantikan proses pemerasan sari empon-empon dari empon-empon yang sudah diparut yang biasanya dilakukan dengan cara membungkus empon-empon parut dalam kain saring kemudian diperas dengan menggunakan tangan.

Penepungan empon-empon hasil kristalisasi (kristal gula+sari empon-empon) selama ini dilakukan Mitra 1 dengan menggunakan blender kapasitas kecil dengan sistem batch. Akibatnya proses penepungan menjadi lama. Untuk mengatasi tersebut, mitra mendapat fasilitasi penepung kecil sistem kontinyu (Gambar 1) 

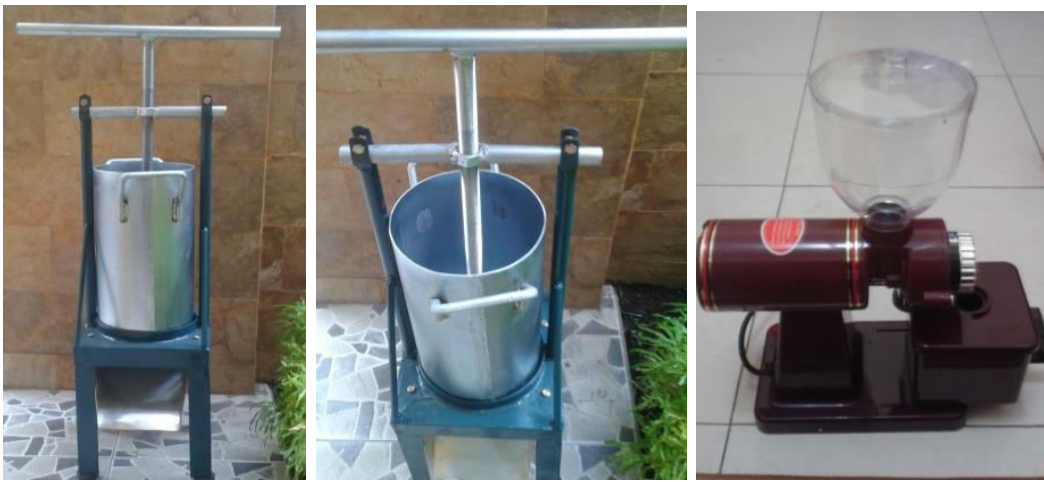

Gambar 1. Mesin pengepres sari empon-empon dan penepung

Permasalahan lain yang dihadapi Mitra 1 pada produksi minuman herbal instan adalah proses kristalisasi yang terbatas menggunakan wajan ukuran rumah tangga karena kompor yang digunakan juga adalah kompor gas rumah tangga. Akibatnya untuk $5 \mathrm{~kg}$ bahan, mitra memerlukan waktu kristalisasi 3 jam. Mitra menginginkan kompor dengan kapasitas lebih besar dalam bentuk kompor cor industri (Gambar 2) sehingga dapat menggunakan wajan ukuran $20 \mathrm{~kg}$ yang sudah dimilikinya.

Peningkatan kapasitas ekstraksi juga dilakukan dengan meningkatan kapasitas perebusan. Kapasitas perebusan ditingkatkan dengan menfasilisi Mitra 2 dengan panci perebus ukuran $75 \mathrm{~L}$ dan kompor cor industri untuk perebusan (Gambar 2). Sebelum lebaran ketika pemesanan datang, Mitra 2 telah membeli panci perebus dan kompor cor juga. Adanya 2 panci dan kompor akan memeudahkan mitra untuk proses ekstraksi dan perebusan/sterilisasi cup yang sudah diisi minuman herbal.

Permasalahan lain yang dihadapi Mitra 1 pada produksi minuman herbal instan adalah proses kristalisasi yang terbatas menggunakan wajan ukuran rumah tangga karena kompor yang digunakan juga adalah kompor gas rumah tangga. Akibatnya untuk $5 \mathrm{~kg}$ bahan, mitra memerlukan waktu kristalisasi 3 jam. Peningkatan kapasitas produksi Mitra 1 dengan kapasitas pemasakan/kristalisasi lebih besar dalam bentuk kompor cor industri (Gambar 2) sehingga dapat menggunakan wajan ukuran $20 \mathrm{~kg}$ yang sudah dimilikinya.

Mitra 1 menghadapi masalahan proses pengecilan ukuran kristal yang tidak efisien karena menggunakan blender ukuran rumah tangga dengan kapasitas 250 g per proses (6 menit). Peningkatan kapasitas dan efisien-si ekstraksi sari empon-empon dilakukan menggunakan mesin pemarut kecil dan pengepres kecil. Selama ini Mitra 1 memarutkan empon-empon ke pasar dan dipres menggunakan kain saring secara manual. Penggunaan pemarut kecil dan pengepres portable akan membantu Mitra 1 untuk mengefisienkan proses produksinya. Kedua alat tersebut saat ini masih dalam tahap pemesanan.
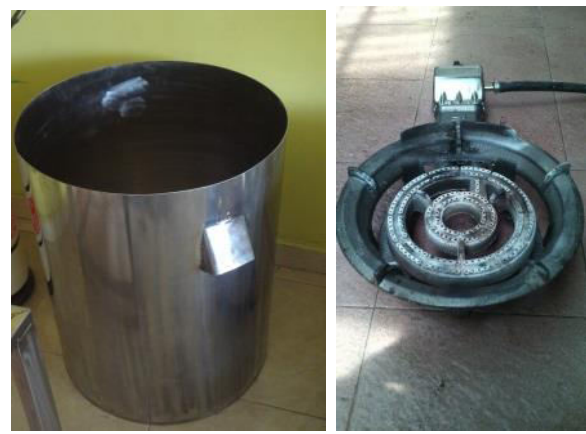

Gambar 2. Panci perebus dan kompor cor industri 

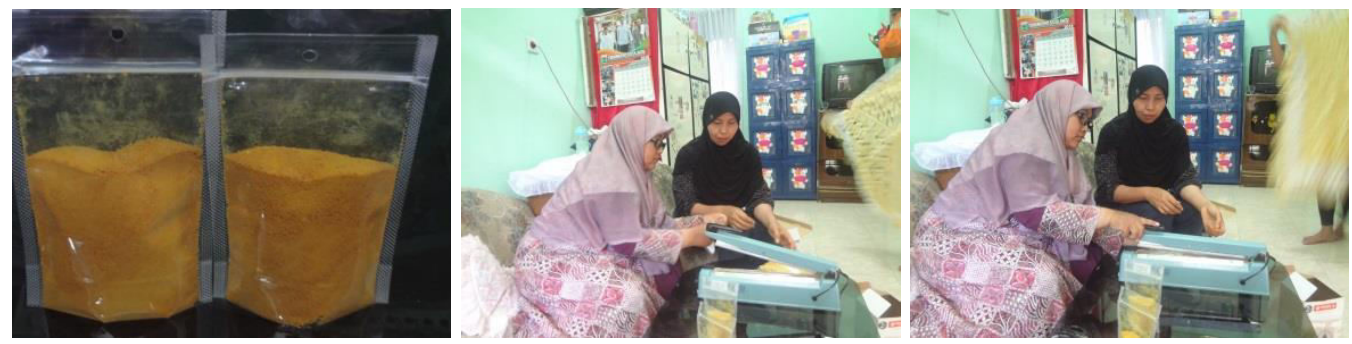

Gambar 3. Minuman herbal instan dalam kemasan pouch dan sealing dengan hand sealer

Untuk menghancurkan kristal minuman herbal instan, Mitra 1 biasa menepungkan menggunakan penepung di pasar. Tahap ini menjadi tidak efisien karena Mitra 1 memerlukan waktu untuk ke pasar. Alih teknologi mekanis menggunakan mesin penepung ukuran kecil dapat mengefisienkan proses pengecilan ukuran. Alat penepung tersebut saat ini masih dalam tahap pemesanan. Tim Pelaksana kesulitan mencari spesifikasi alat penepung yang sesuai. Mesin penepung yang ada berupa disc mill mempunyai daya listrik yang besar yaitu $1500 \mathrm{~W}$ yang tidak sesuai untuk daya listrik di rumah Mitra 1. Oleh karena itu, proses penepung yang diberikan kepada Mitra 1 adalah penepung kopi dengan daya $350 \mathrm{~W}$.

\section{Perbaikan kemasan dan label produk minuman herbal}

Permasalahan yang dihadapi Mitra 1 terkait pengemasan minuman herbal instan adalah proses pengemasan yang masih tradisional menggunakan api dan proses penimbangan yang menggunakan timbangan kue. Akibatnya Mitra 1 seringkali tidak dapat mengemas dengan baik dengan berat yang tepat. Hand sealer manual dibutuhkan mitra untuk mengatasi masalah tersebut. Penimbangan dengan timbangan digital akan membantu mitra untuk meningkatkan presisi dan akurasi penimbangan.

Perbaikan kemasan minman herbal instan dilakukan dengan memperbaiki jenis kemasan dari plastik biasa menjadi kemasan pouch (Gambar 3). Hanya saja proses desain label belum selesai sehingga belum ada bantuan label untuk Mitra 1. Plastik kemasan pouch yang diperkenalkan kepada Mitra 1 mempunyai lid sehingga setelah kemasan dibuka, konsumen dapat menutup kembali. Adanya fasilitasi hand sealer (Gambar 8) membantu Mitra untuk mengemas menggunakan plastik yang lebih tebal.

Diversifikasi kemasan minuman herbal dilakukan dengan membuat minuman herbal dalam kemasan cup. Mitra memang mempunyai rencana untuk memproduksi minuan herbal cup. Proses produksi minuman herbal cup kadang-kadang dilakukan Mitra 2 dengan meminjam cup sealer ke sesama produsen minuman cup. Fasilitasi cup sealer manual dapat membantu Mitra 2 untuk diversifikasi kemasan yang lebih menjual.
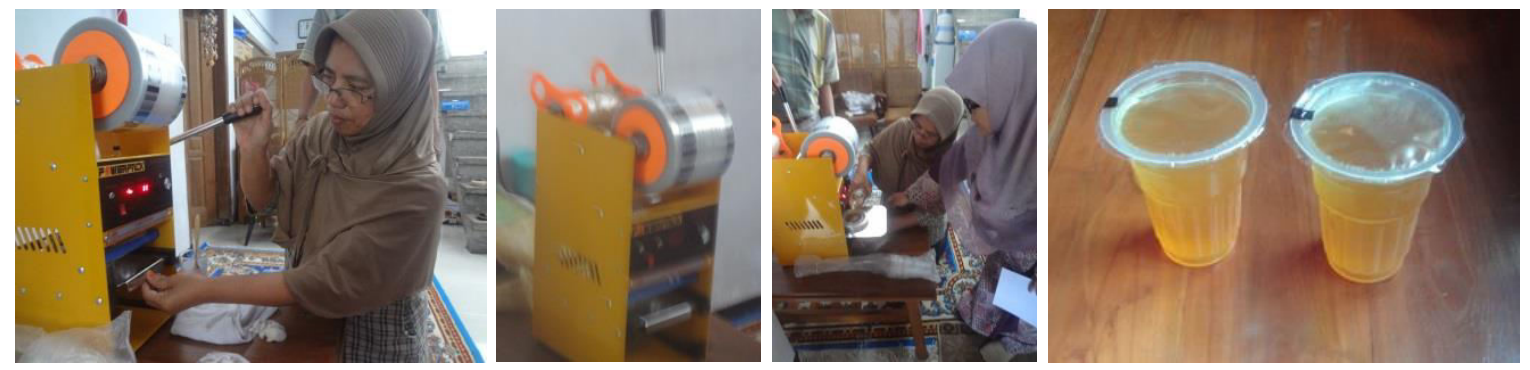

Gambar 4. Cup sealer dan proses sealing minuman herbal dalam kemasan cup 
Mitra berencana memproduksi minuman herbal dalam kemasan cup 110 ml. Cara-cara pengemasan dan fungsi-fungsi setiap tahap dalam produksi minuman herbal kemasan cup telah disampaikan kepada Mitra 2. Mitra 2 harus memahami fungsi-fungsi tersebut sehingga minuman herbal cup yang dihasilkan bermutu baik dan daya simpan awet. Umumnya daya simpan minuman kemasan cup sekitar 6 bulan. Hasil pengemasan dengan menggunakan cup sealer dapat dilihat pada Gambar 4.

\section{Perbaikan mutu produk minuman empon-empon}

Permasalahan yang dihadapi Mitra 2 dalam produksi minuman empon-empon adalah pengendapan selama penyimanan, distribusi, dan pemasaran sehingga produk menjadi keruh. Hal ini disebabkan karakterisik bahan baku minuman emponempon yang kaya dengan fenol dan tanin. Untuk menurunkan tingkat pengendapan, proses sentrifugasi dengan menggunakan alat sentrifusa (Gambar 5) dapat mempercepat proses pengendapan. Dengan menggunakan alat sentrifuse, proses penyaringan minuman herbal dengan kain saring yang biasanya dilakukan sebanyak 2 kali, tidak lagi perlu dilakukan. Proses senrifugasi selama 10 menit sudah mampu mengendapkan endapan yang terbentuk selama proses pengolahan minuman herbal.

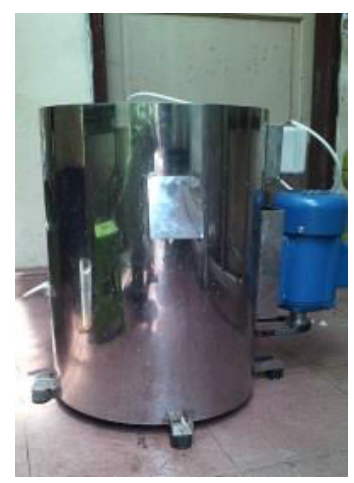

Gambar 5. Sentrifusa untuk penghilangan endapan minuman herbal

\section{KESIMPULAN}

Efisiensi proses produksi minuman herbal instan telah dilakukan dengan alih teknologi proses pemerasan sari emponempon menggunakan mesin pengepres. Pengecilan ukuran kristal dapat dilakukan dengan menggunakan mesin penepung sistem kontinyu. Peningkatan kapasitas kristalisasi juga dilakukan dengan fasilitasi mesin cor industri sehingga mitra dapat menggunakan wajan dengan ukuran besar. Peningkatan kapasitas produksi minuman herbal dilakukan dengan peningkatan kapaistas ekstraksi mengguankan panci ir kaat ukuran besar dan kompor cor industri. Proses perajangan yang selama ini dilakukan manual telah ditingkatkan kapasitasnya menggunakan mesin perajang empon-empon. Selain itu, peningkatan mutu supaya sari empon-empon tidak mengendap selama pemasaran dilakukan dengan fasilitasi alat sentrifusa. Diversifikasi kemasan sari empon-empon dilakukan dengan fasilitasi cup sealer sehingga mitra dapat memproduksi minuman cup yang lebih marketable.

\section{UCAPAN TERIMA KASIH}

Ucapan terima kasih disampaikan pada Kementerian Riset, Teknologi dan Pendidikan Tinggi atas pendanaan kegiatan melalui skim Iptek bagi Masyarakat (IbM) Tahun 2016 dengan Nomor Penugasan: 019/SP2H/ PPM/DRPM/II/2016 tanggal 18 Februari 2016, serta Lembaga Penelitian dan Pengabdian kepada Masyarakat (LPPM) Universitas Brawijaya.

\section{DAFTAR PUSTAKA}

Al-Kennany E A L and A I Al-Khafaf. (2010). Effect of rosella extract on development of fatty streaks lesions in female rats. Iraqi Journal of Veterinary Science 24(2): 81-85 
Alshami I and A E Alharbi. (2014). Antibacterial effect of Hibiscus sabdariffa (Roselle) extract in synergism with voriconazole and fluconazole against fluconazoleresistant Candida albicans isolates: An in vitro study. Biomedical Research 25 (3):401-404

Anonim. (2013). Khasiat Kunyit sebagai Obat Tradisional dan Manfaat Lainnya.Warta Penelitian dan Pengembangan Tanaman Industri 19(2): 5-9

Chao C-Y and M C Yin. (2008). Antibacterial effects of roselle calyx extracts and protocatechuic acid in ground beef and apple juice. Foodborne Pathogens and Disease. DOI: $10.1089=$ fpd .2008 .0187

Duke J A. (2002). Handbook of Medicinal Herb. Second Edition. CRC Press, USA

Gautam M K, A Singh, C V Rao, and R K Goe. (2012). Toxicological evaluation of Murraya paniculata (L.) leaves extract on rodents. American Journal of Pharmacology and Toxicology 7 (2): $62-67$

Haniadka R, A Saxena, A R Shivashankara, R Fayad, P L Palatty, N Nazreth, A Francis, R Arora, and M S Baliga. (2013). Ginger protects the liver against the toxic effects of xenobiotic compounds: preclinical observations. J Nutr Food Sci 3:5

Hemalatha K, D Sunitha, and Satyanarayana. (2011). Cytotoxic activity of ethanolic extract of Caesalpina sappan Linn and Anaona squamosa Linn in a 549 cell line. Int. J. Pharm and Ind. Res.

Lisdiana. (2004). Pemanfaatan rimpang kunir putih (Curcuma zedoaria) sebagai pengurang kerusakan struktur mikroanatomi hepar mencit akibat alkohol. Berk. Penel. Hayati 9:119123

Muhtadi A, R Hendriani, and R Mustarichie. (2013). Pharmacological screening of various indonesian herbals potentially used as antidiabetic. Int. Res J Pharm. App Sci. 3(1): 90-9

$\mathrm{Ng}$ M K, Y Abdulhadi-Noaman, Y K Cheah, S K Yeap and N.B. Alitheen. (2012). Bioactivity studies and chemical constituents of Murraya paniculata (Linn) Jack. International Food Research Journal 19(4): 13071312

Srinivasan R, G G Selvam, S Karthik, K Mathivanan, R. Baskaran, M Karthikeyan, M Gopi. (2012). In vitro antimicrobial activity of Caesalpinia sappan L. Asian Pacific Journal of Tropical Biomedicine S136-S139.

Ying, W M, B J West, C J Jensen, D.Nowicki, S U Chen, A Palu, and G Anderson. (2002). Morinda citrifolia (Noni): A literature review and recent advances in Noni research. Acta Pharmacol. Sin. 23 (12): 1127 -1141 